\title{
Torgny T. Segerstedts pris för bästa artikel i Sociologisk Forskning 2018 och 2019
}

Torsdag 19 mars, i samband med årsmötet för Sveriges Sociologförbund, tillkännagavs mottagarna av Torgny T. Segerstedts pris för bästa artikel i Sociologisk Forskning, för årgångarna 2018 och 2019 av tidskriften. Priset har delats ut sedan 1995 och bär sitt namn efter Sveriges första professor i sociologi.

Följande motivering till årets utdelning gavs av juryn:

2018

Priset för Sociologisk Forsknings bästa artikel 2018 går till "Unveiling the radical right online. Exploring framing and identity in an online anti-immigrant discussion group" av Anton Törnberg och Mattias Wahlström. I denna artikel analyseras innehållet i diskussionsgruppen Stå upp för Sverige, som utgör ett belysande exempel för en typ av politisk aktivism som har fått allt större genomslag i det svenska politiska landskapet. Detta sker med en kreativ kombination av kvantitativa och kvalitativa metoder, samt genom att förena teorier från olika forskningsfält. Artikeln bidrar till en fördjupad förståelse för såväl politisk mobilisering som formering av kollektiv identitet, som har relevans även för andra former av politisk aktivism.

Artikeln publicerades $i$ Sociologisk Forskning volym 55, nr 2-3. Törnberg och Wahlström är verksamma vid Göteborgs universitet.

\section{9}

Priset för Sociologisk Forsknings bästa artikel 2019 går till ”Den egna erfarenhetens marknad. Om brukarinflytandearbete och kommodifiering av individers erfarenheter av psykisk ohälsa” av Erik Eriksson. Artikeln bygger på ett gediget empiriskt underlag och identifierar och belyser en intressant utveckling vad gäller brukarinflytande i psykiatrin. Resultatet av studien bidrar till den sociologiska beskrivningen av samhällsutvecklingen i stort, men är dessutom högst relevant för hur man inom vårdsektorn (och liknande sektorer) lägger upp sitt arbete med brukarinflytande.

Artikeln publicerades i Sociologisk Forskning volym 56, nr 2. Eriksson är verksam vid Linköpings universitet.

Juryn bestod av Jenny-Ann Brodin Danell, Umeå universitet, och Sverre Wide, Örebro universitet. 